\title{
Sign Story: Shifting Discourse on 'signage' in Progressive Grocer Magazine, or the Supermarket Under Late Capitalism
}

\author{
Mario Rodriguez
}

The supermarket industry is an "industry in flux." [1] Modern grocery stores face multinational opposition at the millennium paralleling the extinction of neighborhood "mom-and-pop" stores with the rise of chain stores of the late 19th century (Strasser, 1989). With this large-scale reorganization of the grocery store industry comes a concomitant restructuring of what constitutes a grocery store itself - its architecture, services, and signs. The following study analyzes the evolving discourse on signs — or 'signage,' as it is called in the industry-in Progressive Grocer magazine over the 12-year period from 1996 to 2008. First, signs are contextualized in terms of the history of in-store marketing, beginning with the birth of packaging that accompanied the shift away from neighborhood stores to chain stores at the close of the 19th century. This transformation parallels the change supermarkets faced at the close of the 20th century in response to consolidating forces, out of which emerged a new strategy for survival in the form of highly integrated customer-oriented marketing. This marketing strategy encompasses a number of themes, including streamlining organization of the grocery store to maximize profit, outsourcing of store design, re-evaluation of the role of labor and the creation of new in-store environments emphasizing customer experience. These conflate with the fragmentation of what has traditionally been called a sign. Finally, the study looks at some possible future trends for signage, including the integration of RFID into shelves, the increasing struggle to win space in shelf-ads, and a vision for the overhaul of the entire spatial construction of the store. The development of signage as a source of revenue in-and-of itself is considered in the context of emerging surveillance networks, and also from the perspective Baudrillard's theory of symbolic exchange and the meaning of commodity fetishism under advanced capitalism.

\section{Literature Review: Fin de siècle stores \& The Birth of Modern Packaging}

In the mid-to-late 19th century, the retail environment was changing rapidly. Boorstin (1973: 101-104) described how new technologies transformed the urban landscape to produce "consumer palaces." With the growing trend of laying down streetcar tracks in major U.S. cities, urban and suburban shoppers could be transported directly to city center, drawing residents away from local markets to a more centralized shopping district. The idea of going on a shopping excursion was born. Innovations such as the elevator led to the modern high rise, and thus the modern department store. Glass windows contributed to the inchoate mystique of the department store. The idea of "window-shopping" was born.

Strasser (1989: 24, 25) suggested that, besides streetcars, a growing telephone network increased the prevalence of impersonal commercial transactions. A legal system more streamlined to the needs of large distributors, which extended legal protections to corporations, facilitated consolidation of the marketplace. By the early 1920's several chain stores were operating, much to the dismay of traditional neighborhood stores. These chains included, for 
example, The Great Atlantic \& Pacific Tea Company (A\&P) (Boorstin, 110, 111).

Strasser (1989: 23) noted that the appearance of industrialized products began in the 1880s and was concurrent with the rise of modern advertising. Strasser chronicled the first example of pre-market research for a product, Crisco, a byproduct of Proctor \& Gamble's (P\&G) Cottonelle. Yet P\&G and other companies at the turn of the century were still reliant on tens of thousands of small merchants to deliver and present their products to customers. Manufacturers courted local merchants through salesmen to display and recommend products.

Part of the mechanism that helped to level the playing field of modern consumerism was the realization among manufacturers that packaging could be used to democratize prices (Boorstin: 108), and as a novel way to differentiate products from competitors (Strasser: 32, 37). In the late 19th century, and despite the rise of some national products such as Ivory soap, the American public still "did not necessarily connect the symbolism and information on product labels with their expectations about the products.

Gradually however, Americans made the connection as they were barraged from a multiplicity of sources that cultivated brand recognition, including magazines, newspapers, and billboards. Turow showed, for example, that "the synergy of advertisements and in-store packaging recalled ads that aimed to give goods personalities so that consumers would choose those specific products, not those of competitors, even if the price was higher" (2006: 26).

From the mid-1800's through the 1930's, American manufacturers who initially were hesitant to package their products for fear of losing customer recognition discovered a way to distinguish their products on the shelves by making them into something novel—a "branded good" (Strasser: 32). Similarly American consumers learned to interpret a "synergy of advertisements," as Turow put it, resulting in brand recognition.

As late as 1923, two-thirds of American business was done at local "mom-and-pop" stores, mainly family run and central meeting places for communities. They were particularly central to immigrant communities, and also frequently extended store credit to customers. Partially because of this tendency to extend credit, however, these stores frequently failed, and by the early 1900's even "stores that stayed in business did so precariously." The fact that they did not keep their money in banks also was a problem (Strasser: 65-73). Centralized markets, brand recognition, and industrially produced goods gradually undermined this power position that local mom-and-pop stores enjoyed and placed it instead in the hands of manufacturers.

The climate of consolidation at the millennium hearkens back to the atmosphere of uncertainty and fear among fin-de-siecle neighborhood stores. In the late 19th century, neighborhood stores were being shut down by the emergence of chain stores, such as A\&P. In the late 1990's, local grocery stores were under fire from the totalizing forces of multinational competition. As before, this uneasiness signaled a sea-change from the way in which grocery stores were spatially constructed. At the millennium, new configurations which play up the importance of peripheral services on an equal par with what has traditionally been called the "center store" have been emerging in grocery stores. This has led to other effects throughout the store, such as the growing relevance of customer marketing at retail (CMAR) to maximize profit, as well as a fragmentation and proliferation of what has traditionally been called a sign.

\section{A Brief Word on Method}

A search with keywords "in-store" and "marketing" from January 1996 through December 2000 in Progressive Grocer magazine using EBSCO Host yielded 124 articles. A search with the same keywords over the period from January 2001 through present yielded 299 articles, more than twice as many. Examining the more relevant articles, it became apparent that the term used to discuss signs in the supermarket industry is 'signage.' This is an industry term that references shelf-signs, floor mats, displays and murals among other miscellaneous forms. An EBSCO Host search in Progressive Grocer from January 1996 through July 2008 yielded 21 articles on the topic of signage. Trends throughout the articles are discussed below.

\section{Results: Pre- and Post-millennial Discourse on 'Signage'}

Only four of these articles on "signage" occur before 2001, and these focus mainly on re-iterating the importance of in-store signs which are clear, attractive, and which reinforce "store image." For example, Armata (1996) suggested 
that it is wise to keep an in-store marketing employee, someone with vision, "an invisible hand that leads customers through the store aisles and directs them to targeted products, strategically linking purchase decisions to the store's external advertising." Smith (1996) reiterated this point, noting the facility of having someone on staff with creative flare for attractive signs. Lewis (1998) encouraged a return to the essence of the supermarket business-that is, food-through beautiful ads that incorporate in-store signage.

In a 1999 editorial from Progressive Grocer entitled “The Eyes Have It," the author emphasized the importance of cleanliness and clear marking of prepared foods, as former deli executive for Central Market in Texas Mark Garcia said "let the food do the talking." Advice included basic strategies such as stirring mayonnaise-based salads to keep them looking fresh. The editorial also recommended lucid signage incorporating a variety of colors in the deli, as well as eye-level signs, menus, chalkboards, and a logical configuration. They cautioned against over the top displays, which might give the impression of high price. One strategy was to focus on the deli and prepared foods. Pizzico (1997) stressed the importance of realizing the distinction between food sales and retail food sales in the grocery store, to ensure a successful "Retail Culinary" program.

Hammel (1997) chronicled D\&W's innovative "Market Square Meals" section, including a chef that prepared meals before onlookers. Hammel mentioned the main bonus in sales came from peripherals like spices and capers. He also discussed the innovation of an in-store Manhattan Bagel Company franchise, and subdivision of the deli into specialized sections (pizza, sandwiches, etc.). This specialization yielded more efficient workers. This trend conflated with new marketing techniques:

The new store's use-defined layout reflects D\&W's extensive and ongoing shopper reconnaissance, in the form of focus groups, surveys, loyalty-card data and toll-free hotline. Staffers had input as well, and the research is paying off. The 62,000-square-foot unit, D\&W's biggest, has also been posting the company's highest weekly volume since its July 30 launch. (Hammel, 1997: 117)

Radice (1997) examined how small supermarkets (less than 50,000 square feet) attempted to increase profits in the late 1990's in three ways. First, some stores reduced the total number of SKU's (2000 out of a total of 9000) to eliminate slow moving products. Other markets focused on seasonal promotions for Christmas and Halloween. Lastly, some stores focused on new technology, such as kiosks.

An excerpt from the Progressive Grocer annual report in the December 1997 "Targeting the Consumer" recommended the use of kiosks, database marketing and frequent shopper programs to better target shoppers in the face of relentless pressure from competitors. The article mentioned recent growth in in-store media programs, "ranging from coupon dispensers at the point of sale to electronic coupons at the checkout. There's no sign of any of this activity letting up, particularly as retailers begin to look at the increased marketing possibilities available in the form of in-store kiosks." This issue of Progressive Grocer included a roundtable with grocery store executives, in which Gary Persinger, V.P. of perishables merchandising for Harris-Teeter in Charlotte, N.C., suggested that to make up profit through prepared foods, the store owners needed to tailor meals to patrons by knowing their "demographics and psychographics." "One of the best promotions I've seen is from Price Chopper, which asks: "Why go to the hut for pizza or Boston for chicken?”' he said.[2]

The grocery store was increasingly viewed dichotomously between the peripherals, such as deli and floral departments and in-store franchises, and the "center store," which still produced $50 \%$ of total profit (Matthews, 1998). As it dawned on store owners that lost profits could be made up through the sale of peripherals, such as perishable foods, the shape of the grocery store began to change to showcase the various departments. At the same time, the nature of marketing had to become more customized through the integration of POS coupon dispensers, databases, frequent shopper cards, and kiosks into the shopping environment, fragmenting retailers' traditional concept of a sign.

The industry dialog surrounding "signage" in the supermarket was not particularly prolific, nor was it all that advanced prior to 2001. Signs were seen as medium through which to present the real selling point of the store-food. However, there are some hints that signs themselves might be an important area for future investment, such as the brief 1996 report that mentioned the services of CIP International, a company specializing in in-store marketing displays. What follows represents some findings about the external pressure of Wal-Mart on grocery stores at the millennium and the way it influenced the changing function or signs in the store, in terms of the variety of signs, use of plane screen television, outsourcing, employee responsibility, physical layout of the store, and the use of signs in an informational and entertainment capacity. 


\section{The Role of Wal-Mart}

At the root of this reorientation and customization was some Wal-Mart skullduggery. "Orphans in the storm" (Matthews, 1998) and "Uneasy alliance" (Lewis, 1998) suggest the disturbing rapidity with which Wal-Mart tightened its grasp over the supermarket world. In "Orphans," Matthews presented the dilemma of store managers trying to maximize profit from the "center store" with the growing importance of fresh foods and perishables, and broached the issue of utilizing customer reward cards to mine data from customers. In the article Ken Robb, senior vice president of marketing at Broadbeck Enterprises in Wisconsin, emphasized that, though profits were floundering because of Wal-Mart's influence, the "center store" still represented 50\% of total profits:

[Wal-Mart has] an unassailable pricing advantage. So what does that tell you? To me, it reinforces the futility of trying to 'out Wal-Mart' Wal-Mart and using the grocery department to do it...You can't simply turn away from the center of the store, but, by the same token, you can't look at it in the conventional manner and make assumptions in light of what's always worked. (Ryan, 1998: 24)

Lewis also alerted readers to the advent of Wal-Mart TV in the December 1997 issue, which was broadcast on screens in 1,950 stores throughout the country. He seemed to be suggesting it as a tactic for reeling independents. In-store TV networks could supplement the plethora of marketing customization suggestions-kiosks, database marketing, frequent shopper programs - which were also recommended that month in the article "Targeting the Consumer."

Lewis described attempts by local supermarkets to fight back against Wal-Mart ("Uneasy Alliance”). He focused on Todd Mastroianni, V.P. Buckeye Village Markets, a five-store IGA independent run by the Mastroianni family for 50 years, forced to compete with Wal-Mart when one opened nearby. [3] Mastrioianni stressed that there is no competition with Wal-Mart on price. Thus, Mastroianni had recently refurbished his store at a price of $\$ 2$ million, with $40 \%$ more space for produce alone. Profit from the deli and produce sections was up every week since the WalMart opening.

More bad news for independent grocery store owners came in March 2001 when Turcsick and Summerour reported that Wal-Mart announced plans to double the number of its Supercenters to 1,900 in the coming years, as well as Neighborhood Markets, leading "300 supermarkets to shutter in the process." They recommended eight strategies to compete, such as "Don't fight Wal-Mart on price unless you know you can beat them.” Turock summed it up best in "Wal-Mart proofing the store" (2003) when he encouraged small stores to compete with Wal-Mart in easily won markets, such as niche segments or through customizations, rather than trying to beat them head on with sales:

Wal-Mart's business model is designed to compete above the fray of supermarket incumbents. Its sustainable advantage builds on a super-efficient distribution system, advanced information systems, mass customization of stores, a saturation strategy that deters competition, a non-union labor force, and a higher-margin general merchandise line that allows food categories to operate at low prices. Overcoming just one of these elements is difficult for a supermarket, and Wal-Mart has become a formidable rival through a robust business model that simultaneously incorporates all of them. (Turock, 2003: 53)

Loyalty cards continued to be among the suggestions to maximize store profit to survive in a Wal-Mart world ("Lazy thinking won't be rewarded," 1998), which could even be used in conjunction with kiosks to data mine customers, particularly in customized areas like the pharmacy or wine department (Lewis, "Box Stores," 1998). At this point, however, the signs were still not seen as a potential cash flow area in themselves, but mainly as a means to reinforce "store image" (Turcsik, "Signs of the Times," 2001).

\section{An Array of Signs}

In response to the aggressive business tactics of Wal-Mart, the economic effects of which were exacerbated by the recession of 2002 (Turcsik, 2002), supermarkets began seeking new avenues to make up for losses in the slim profit margin enjoyed annually_ as little as 1\% (McHugh, 2004). Some of these, as mentioned, included customized shopping initiatives such as frequent shopper programs, key cards, kiosks, and increased emphasis on CMAR, all of which integrated nicely with data mining.

However, these also affected the interaction of shoppers with signage. Those in the know began to view signs not merely as tools to direct customers to food or reinforce "store image," but rather as a driving force for profit in and of themselves which could be used to cross-reference products, provide information, and spark interest. In essence, the discussion of signage matured in 2001, and with it, the meaning of the term expanded into a spectrum 
of possibilities.

In October 2001, Progressive Grocer published a comprehensive article about in-store signage. The emphasis shifted away from the hum-drum rhetoric about the importance of signage to innovation in the realm of in store marketing (Turcsik, "Signs of the Times," 2001). Some of these new forms of signage included high resolution digital prints called "Lambda C's," plasma TV's, "Sunspots" (a kind of Lite-brite style display), "SmartPaper," small rotating billboards, leasing space on shopping carts, and boutique-style in-store awnings.

These innovations had practical implications. For example, incorporation of market-style facades into the instore environment, such as artificial brick-walls and awnings to create a "boutique-style décor," gave the appearance of "walking along a city street." "SmartPaper," developed by Gyricon Media, Inc., of Palo Alto, CA, was being trial run in the children's department of a Macy's in Bridgewater, New Jersey. It was hoped that the "SmartPaper" would rectify the chronic problem of never being certain if employees had changed all the signs after a sale.

Signage innovations were a means to optimize profit, guide traffic patterns, convey information to the shopper, reinforce a coherent store image, suggest purchasing options, and prompt shoppers to buy. This would be done both by streamlining the pricing visibility, as with the "SmartPaper," and also by viewing signage as a new "profit center" in itself on par with "front-end merchandisers."

More recently, Turcsik (2003) wrote about signage innovations that generate theater type excitement, such as floor tiles, web-based customized digital prints, and even the "Promotional Railroad," an advertisement mounted toy train that runs over the checkout lane. One article mentioned a cool, flexible neon-substitute called "GELLcore" "Neon effect LED lighting," 2005), and another discussed new wall-mounts for large-scale flexible signage ("Equipment innovations," 2006). Tarnowski ("Gone Fishin'," 2006) reported on sign innovations such as the SwingStrip (meant to replace the J-hook), a cross-merchandising solution for selling hairbrushes with shampoo, or spices with readymade meals. The plethora of new signs embodied emergent efforts in the industry toward integration of products, creation of in-store environments, and the re-presentation of products in a bombastic way to excite customers.

\section{Plane Screen TV}

Grocers first caught wind of the potential of plasma TV's in 1997 when Lewis reported in Progressive Grocer that Wal-Mart planned to roll-out its own broadcast station on screens in 1,950 stores nationwide. Turcsik mentioned plasma TV's, suggesting that they might be incorporated into endcaps, the displays at the ends of aisles ("Signs of the Times," 2001). Plane screen TV's in-store could be used to change content on the fly. The motion attracted attention, putting it in a similar category as the splashy, large-scale Lambda C digital prints and Lite-brite-like "Sunspots." Colicchio (2002) added that plasma screens were rapidly dropping in price. Sarasota, Florida, based RDM developed a router for in-store television networks to plug local content into a satellite stream ("The digital shuffle," 2006).

Again, Wal-Mart was the trendsetter in this area. Despite suspicion about the utility of investing advertising dollars into Wal-Mart's television network, which some suggested is more of a "good faith" gesture to the merchandizing giant (Frazier, "Is Wal-Mart TV a smart by or a defensive one?," 2005), Albertson's unveiled plans in spring of 2005 to roll out its own television network in 2,500 stores (Frazier, "In-store advertising model gains ground," 2005).

\section{Outsourcing In-store Signage}

Part of the signage dialogue involved discussion of hiring outside agencies to design signs in the store. There is an early example of this with the ads for in store marketing specialists in the December 1997 issue of Progressive Grocer specializing in lighting, floor design, and merchandising lay outs. Turcsik's article on "In Store Marketing 101" (2003) mentioned the use of display kits from Dismar Corporation, a sales promotion and point of purchase display manufacturer. Dismar offered a boxed kit for a festive Halloween display. Tarnowski discussed how Minnesota based Cub Foods hired Gladson Interactive to design digital signs that were blow-ups of produce, to boost produce sales ("Picture Perfect," 2003).

Turcsik quoted National Association for Retail Marketing Services (NARMS) president Gary Ebben, who reinforced the idea that stores must create "niches" for themselves in "customer service" and as "customer-friendly" stores in the spirit of "event-marketing and demonstration and sampling" sweeping the retail industry. Looking to outside companies to manage displays frees up time for employees to focus on creating an experience for customers.

\section{Shifting Role of Employees}

The shifting role of signage in the supermarket is linked to a residual effect on the role of supermarket employees. 
As Pine and Gilmore (1999) described in "The Experience Economy," in a competitive age marketers should attempt to transform commodities, goods and services into experiences for consumption - that is, they should gerund them (14). They give the example of a cup of coffee, which can be enjoyed inexpensively, or when served a high-end café, can be an experience in itself (3).

As Ebben suggested, hiring outside companies to create in-store displays and signage which integrated datamining for a more customized shopping experience opens up time for employees to focus on creating a shopping experience for customers. In "In-store marketing," Turcsik mentioned that installing gravity fed shelves allowed employees to spend less time stocking and more time interacting with clientele. For example, one high-end cheese shop in Wisconsin employed a complex system of signage to supplement expert staff and inform otherwise shy shoppers (Major, 2004).

The experimental "Shopping Buddy" created by Ahold USA is another example of the undulating terrain of labor in the supermarket. Turcsik (2003) wrote that Shopping Buddy, a shopping cart mounted display, had been test run on a 1,000 shopping trip assessment from 1999 through 2000. The makers hoped Shopping Buddy could resolve key issues of assisting with a purchase, getting through the checkout quickly, finding items in the store, and finding information about products, all issues related to competency of employees. According to a CBSNews.com report from 2005, Shopping Buddy had been test run in a Stop \& Shop in Braintree, Mass., and the food chain planned to equip 20 more stores by the end of the year. Turow too noted that Albertson's Scan \& Shop and Stop \& Shop's Shopping Buddy have been somewhat successful in test markets (Turow, 2006: 146, 147).

\section{CMAR}

Customer marketing at retail, or CMAR, took on increasing significance in the Wal-Mart ruled world. Turcsik ("Category-weis-er," 2001) broke down Anheiser Busch's system for "category management" that "recommends a list of core and optional sku's" for the optimization of sales of carbonated beverages, salty-snacks, and related paraphernalia. He quoted Alan Katz, V.P., Display Technologies: signs were adding to the supermarket's "bottom line. Signage programs are becoming a profit center, much like front-end merchandisers," (Turcsik, "Signs of the Times," 2001). Turcsik (2002) also reported the top companies in the area of CMAR, with P\&G holding the number one place as Kraft (2) and General Mills (3) making great strides. Signs developed a function for profit optimization, whether to route customers to the right products or free up employees to cater to the clientele. CMAR was closely intertwined with this function.

\section{Store Layout}

Craig Childress of the New York behavioral marketing company Envirosell argued for a more customercentered spatial orientation for both signs in the retail store and for the layout of the store itself. Childress described a "decompression zone" in the first 12 feet of the supermarket in which no signs should be placed because this is a space in which customers shift gears from being on the street. He warned of a "saturation point," at which people who are bombarded by too many signs have a tendency to shut down and start looking at the people around them rather than signs. Too few signs run the risk of boring the customer and making waiting time seem longer. With a consistent signage scheme, customers can be trained "like ducks in a shooting gallery," particularly at the checkout (Childress, 2005: 80).

\section{Signs as Entertainment}

Signs also have entertainment value, particularly with reference to Pine and Gilmore's observation that marketers should focus on creating an experience by gerunding services and "sensorializing" goods (14, 17). Turcsik's ("Signs of the Times," 2001) examples of the Promotional Railroad, web-based signs, displays in a box, and Ebben's reference to the growth of "the whole event marketing and demonstration and sampling industry" point to a confluence of event marketing and signage in the grocery store. Tactics included loose flour left out in the deli to create a homey atmosphere, an example of sensorializing the store (Childress and Goldschmidt, 2004), awnings to create boutique style atmospheres and splashy displays that use plasma TV's and floor mats to catch the eye (Turcsik, "Signs of the Times," 2001). High-resolution graphics called "Lambda-C" could be used as wall murals and floor graphics. As Design Fabrications Inc. (DFI) design director Nadine McClearon said, digital representations of facades can even save retailers construction costs: 
There is a trend toward really large, in your face, graphic representations for foods, products, logos or for something that is going on in the store...You can't tell a digital print from a photo, and it's getting that you can't tell real bricks from printed digital bricks being used as wall-covering. We are reducing the retailer's cost by replacing architectural elements, like bricks and windows, with digitally printed images that look three-dimensional. (Turcsik, 2001: 40)

This means that, like backdrops in a theater production, retailers can change textures and ambiance seasonally. Of course, the authors caution against "sensory overload" for shoppers_-signage needs to be used "strategically."

\section{Signs in an Informational Capacity \& Kiosks}

This entertainment function of signs in the grocery store has an equally important flip-side of providing information. At the turn of the 19th century the innovation of packaging increasingly estranged and removed commodities from their representations on the shelves in an effort to reach out to the customer and inform him (Strasser, 1989). Today, examples have cropped up signaling even more complex hierarchies of information in the grocery store. For example, in "The Eyes Have It" (1999), the editors advised deli-case taxonomy-color-coding foods of a similar type. Major (2004) identified a complex coding scheme for a high-end cheese shop to inform uncertain customers. Some signs even go so far as to recommend the best time of day to shop to suit a customer's personality (“In-Store Intel," 2005).

Probably the most extreme example relates to health food labels. Gatty and McTaggart (2006) presented a system of labeling different aspects of health foods to identify healthy alternatives to products on shelves throughout the store. United Supermarkets of Lubbock, Texas, for example, developed a coding system that included "GF for Gluten Free, O for Organic, and HH/DM for Heart Healthy and Diabetes Management.” Ashville, N.C., based Earth Fare initiated shelf labels plus cooking classes geared toward kids to begin informing them about healthy diet early.

Kiosks are playing a larger role in supermarket signage as an informational supplement, profit optimization scheme, and time-saver for shoppers and employees alike. Radice (1997) mentioned them early on as one way, along with reducing SKU's and seasonal promotions, to maintain competitiveness. Kiosks became a way to better customize the shopping experience to customers ("Targeting the consumer," 1997). In "Box Stores" (1998), Lewis recommended kiosks in conjunction with loyalty cards, customized coupons, and departments that lent themselves to customization, such as pharmacy and wine. InterMedia Kiosks of Owings Mills, Maryland saw their sales of the Xpress Deli kiosk ordering system more than double in 2001.

\section{Discussion: Integrated Technology, Surveillance \& Symbolic Exchange}

The supermarket industry is undergoing a radical change reminiscent of the shift from neighborhood stores to chain stores in late 19th century. The underlying forces are multinational, largely due to the totalizing influences of Wal-Mart Supercenters but also due to recession and diminishing returns. The result has been a Balkanization of the in-store signage scheme in the form of large scale digital print outs, boutique-style atmospheres, complex information systems, reliance on kiosks and computerized help, plasma TVs, electronic paper and a host of other forms. The role of signs in the store conflates with overarching trends toward outsourcing signage design, changing the role of employees to emphasize shopping experience, increasing efficiency of returns through programs such as CMAR, and finally creating an environment that is an informational and entertainment blitz.

Media consolidation also played a role in the proliferation of signage at the shelf (Neff, 2006). News Corp.'s News America division produces $\$ 300$ million of in-store advertising per year. News America locked up on-shelf promotions in 35,000 stores nationwide for up to two years by signing multi-million dollar contracts with "toppackage goods" marketers like P\&G. Although allegations of monopoly remain to be proven, in the interim this has led brands locked out of the shelf to diversify their in-store presence, such as Kimberly-Clark Corp.'s Viva paper towels, which opted for shopping cart ads. It might be interesting to see how new forms of signage continue to emerge as in-store sign ownership is increasingly consolidated.

New technology is on the horizon as well, not limited to integration of signage with new media such as electronic paper, Bluetooth and mobile technology, self-check outs and RFID (Colicchio, 2002). A July 2004 article in Wired also mentioned that Smart Paper was being test run in an "Extra Future" store in Rheinberg, Germany. The store was intended to be a testing ground for innovative technology, which included prices on 35,000 LCD labels linked to 
a CPU that provided real-time pricing, and "Smart Shelves" that collected inventory data through RFID technology to be sent to retailers, distributors, and manufacturers.

Other features included customized advertising displays based on customers' demographic data and shopping habits, RFID checkout, Wi-Fi touch screen cart-top computing, and even kiosks for pricing vegetables and giving advice about wine. Gillette, Kraft, and Procter \& Gamble lined up to test products in the store, hoping to enhance the thin profit margin in retail. Wal-Mart has now fit all stockroom pallets with RFID tags (Turow, 2006; 143).

Integration of RFID technology into shelves, products, and stockrooms bodes interesting consequences for instantaneous, store-wide pricing to maximize profit through signs but also for privacy and surveillance. I conclude with a discussion of the broader atmosphere of surveillance in which this transition to an integrated marketplace is occurring, as well as by contextualizing the increased emphasis on visuals in the store with the legacy of commodity fetishism.

\section{Surveillance}

The integration of new media and signage marks the beginning of a trend for profit maximization by visual means in supermarkets, but it also establishes a new level of integration for surveillance. This has already occurred to some extent in the form store loyalty-cards-for example, the use of loyalty-cards by the supermarket chain ShopRite and by CVS drugstores to track customer behavior. Shop-Rite also employs Catalina Marketing, a company that specializes in analyzing consumer purchases over the long term and distributing coupons that maximize store inventory. Loyalty cards could be seen as a kind of precursor to RFID, a technology which promises to fulfill marketers' dreams to hyper-segment consumers. According to Risk Management in 2004, an RFID could be placed on carpets, floors, doorways, and in distribution centers, stores, and homes producing a seamless network for consumer monitoring (Turow: 140-143).

The integration of personally identifiable information with in-store signage fits the post- $9 / 11$ pattern. The everyday activity of shopping becomes one more space intimately bound up with surveillance and networks of flow, reinforcing the attitude of "responsibilization" in emulation of corporate risk-management and lateral surveillance or peer-monitoring in society (Andrejevic, 2005). For example, the security database company ChoicePoint even attempted to market background-check software in Sam's Club in 2003 (Andrejevic: 487). The movement of surveillance into a space as quotidian as the supermarket is one more example of how the post-9/11 atmosphere of intensified, automated surveillance leads government and industry to envision people less as citizens and more as surveillors (Lyon, 2003). The presence of ubiquitous surveillance in the supermarket further normalizes surveillance.

Washington Post reporter Robert O'Harrow (2005) chronicled the accelerating production of surveillance technologies since $9 / 11$. His discussion ranged over a spectrum of topics. This included the more exotic science fiction of biometrics, facial recognition, and the potential use of RFID to track everything from money, to vehicles, to people (through subcutaneous implants) (283-288). Much of his research focused on the cozy relationship between private data clearinghouses and Homeland Security, as well as the everyday people who have slipped through the cracks of modern surveillance systems. While we blithely go about our shopping we are immersed in networks of information flow and there is ever increasing collusion between government and private industry. As O'Harrow concluded, we cannot control where that personal information is going at all times.

Industry discourse surrounding greater integration of personal data to tailor the shopping experience reopens ethical issues at the level of the everyday purchase, for example of price discrimination, whereby people receive different pricing on the same items based on buying history, that is, through coupons generated at the register by Catalina Marketing (Turow, 2006: 141). As noted in the Annenberg Public Policy Center report on Americans and their awareness of what is done with consumer data, $64 \%$ of American adults are unaware that it is legal for an online store to charge different people different prices at the same time of day, and $71 \%$ did not know that it is legal for an offline store to do the same (Turow, Feldman \& Meltzer, 2005: 3). Furthermore, according to an earlier survey, there was strong evidence that "the overwhelming majority of American adults who use the internet at home have no clue about data flows," and that $63 \%$ of Americans who said they had given out personally identifiable information on a website also believed the mere presence of a privacy policy prevents that website from sharing that data with other firms (Turow, 2005: 158-160). This is simply not so.

There is a dual danger implied with intensified industry discussion of integration of personal consumer data with in-store visuals. First, there is the normalization of intensified surveillance in the everyday space of the supermarket, and the corresponding blithe acceptance of increasing collusion between government and corporations, the swapping of one's personal data without one's knowledge, as the transparency of the data flows becomes ever more nebulous. 
Second, there is the opportunity for blatant exploitation at the level of the individual shopper's interactions and purchases, such as with the case of price discrimination

\section{| Baudrillard's 'Symbolic Exchange' \& In-store Signage}

However, there is a third danger inherent in the increased emphasis on the capacity of in-store signage, peripherals, and experience to generate income on par with the revenue from food itself, which is an example of just how far the commodity fetish has gone under conditions of advanced capitalism. The ubiquity of larger-thanlife digital prints of food meant to whet the appetite or create the façade of a traditional market place, increasing emphasis on CMAR, and the assertion of one industry professional that store managers cannot "simply turn away from the center of the store," but that at the same time they cannot "look at it in the conventional manner" are aspects of the transforming nature of the supermarket that require brief consideration in terms of the history of commodities.

We have already seen how reorganization of the market around the year 1900 shifted control into the hands of manufacturers away from local stores. Concurrent with this was the rise of the "branded good" and brand recognition as Americans began to recognize a "synergy of advertisements." This was an initial step in separating the image of the product from the product itself, a schism writ large at the millennium in the language of Progressive Grocer. Two points must be addressed. First, we must trace the origin of this schism between the commodity and its image, and their ever increasing economic equivalence. This discussion begins with Marx and ends with Baudrillard's theory of symbolic exchange. My second point will contextualize the modern approach of grocery stores to generating income visually within Baudrillard's later theory that goes beyond symbolic exchange to describe a networked model of late capitalism.

Marx (1999: 1887) broke the commodity down into use-value and exchange-value. The use value of the commodity is the substantive value of the material thing. It is the pragmatic end to which a commodity can be put to sustain economic productivity. On the other hand, the exchange-value is the value of the commodity in the abstract to the overall well-being of the capitalist economy. Exchange-value is the monetary value, initially perceived as a "quantitative relationship." It is the schism between these two aspects of the commodity-the utilitarian that makes it valuable to the individual consumer, and the monetary that makes it valuable to perpetuating the economic system - that gives rise to surplus value. This is the discrepancy between what people are paid and how much they produce. The net result of this discrepancy is alienation from the labor process and the products themselves. This gives rise to "commodity fetishism." Objects are imbued with a magical value that denies the investment of labor. The denial is the fetishistic aspect theorized by Marx which obfuscates the social relations in a capitalist economy.

It was Jean Baudrillard (1994: 1983) who pushed the relationship between use-value and exchange-value to its ultimate end. He described a breakdown between use- and exchange-value that comes about as a result of a postmodern symbolic economy. This is "symbolic exchange." Signifiers are decoupled from their signs and allowed to float free. Postmodern economic relations privilege signifiers. As a result, all interactions become simulations, which blur the boundary between reality and interfaces, producing a state of hyperreality.[4] Koch and Elmore (2006) suggested that "symbolic exchange" can be used to understand how increased emphasis on the fetish aspect of commodities in the manufacturing process allows capitalism to be self-sustaining, even after "material needs" are met. They trace the development of Baudrillard's theory, from his early interpretation of Marx and elaboration of symbolic exchange, through his work in the early 1980's on the Orders of Simulacra, and later his abandonment of symbolic exchange altogether to describe a late capitalist economy that is networked and holographic - a fractal model.

First, the increasing rhetorical equivalence of visual media and product in Progressive Grocer since the mid1990 s is a prime example of symbolic exchange, and evidence at the most mundane level of human life. No less the emphasis on ready-made 'peripherals' that predominate in supermarkets and industry discussion—-these 'peripherals' are merely a visual display. Even the very "architectural elements" of the store are being replaced by high-resolution digital prints. This is the result of a symbolic economy that conceives of the individual commodity only with reference to its reproducibility, where the "code" of reproduction is society's teleology (Koch \& Elmore, 562). The increased emphasis on the signifier can be traced all the way from the inchoate brand recognition of the early 20th century to the full-blown fetishism in the postmodern symbolic economy and its moribund logic.[5] 
In the late 1980's Baudrillard's thoughts began to move from code and simulation to readdress issues of commodity fetishism. This is the "fractal stage" of capitalism in which the binary of symbolic exchange, code, and object has completely vanished. All that is left are objects which are definable only in relation to the network other objects. Beyond use and exchange value, commodities derive their value only in relation to this network. Not only does this mean a total equivalence of object and network (and thus its "fractal" nature) but that these objects as commodities are pure fetish—the network is beyond representation. The commodity has a "pure symbolic value" (Koch \& Elmore, 564). Furthermore this is the reason that capitalism continues to sustain itself now that "material needs" are met:

[A]ccording to Baudrillard, even [Marx's] logic of the fetish must at some point give way to a higher-order fetishism. Baudrillard suggests that this logic of capitalism will reach a point, as it has in the United States, in which the very structuring of value itself becomes a barrier to productivity, consumption, and capital. Thus the capacity of fetishism to sustain the logic of capital increasingly comes to constitute capitalism itself. (Koch \& Elmore, 571)

This impulse to sustain capitalism through "the capacity of fetishism" is quite apparent in evolving discussion of signage in Progressive Grocer over the last decade. It would be interesting to apply this analysis to the way people have come to interact on a social networking application such as Facebook, where virtual objects are available for $\$ 1$ U.S. In fact, it is even possible to buy and sell your friends on Facebook. [6] Finally, the increased emphasis on signage in Progressive Grocer is everyday evidence not merely of a schism between use- and exchange-value, sign and signifier, code and object, but a total break with reality in favor of a networked form of capitalism in which images, peripherals, and products are all self-referential and possess equal potential for profit. Furthermore, loyalty cards and Catalina machines linked to third party administrators of consumer data entangle shoppers themselves in networks of information flow. Greater integration of this personal information with an array of signs linked to surveillance gadgetry - RFID, Bluetooth, mobile devices, smart paper-means that customers themselves come to be included in the commercial network. Shoppers are packaged and sold as commodities to data clearinghouses and security companies much as if we were little more than products in the display case or avatars on Facebook.

\section{Conclusion: The Future of Grocery Shopping \& Research Suggestions}

We have seen how the discussion of signs in the grocery store has changed over the past decade in a key industry publication. This has implications for the way stores are managed, their layout, and the immediate experiences of shoppers. Signage also has some deeper implications for surveillance society and even the nature of commodities in a late capitalist consumer culture, to the extent that grocery shoppers find themselves embedded in a network of symbolic exchange and beyond-as commodities themselves. This equivalence of signs and products (and human beings and products) is a development as pernicious (if not more) than the dual dangers of normalization of surveillance and blatant exploitation of consumers that arise in the 21 st century supermarket, an everyday semiotic breakdown that signals as much a loss of reality as of humanity. Future studies could investigate the new phenomenon of in-store doctors to compliment the pharmacy ("In-store health clinics gain traction," 2006), and again it might be interesting to follow how media consolidation plays a role in locking up shelf-space and spurring further innovation in in-store signage. It could also be important to map the changing distribution of space within the grocery store over time, linking space with shopping patterns and habits, or perhaps even healthiness of diet.

As for the experience of the supermarket, shopping will forever be altered by the shifting landscape of in-store signs. According to Craig Childress of Envirosell (2003) modern shoppers do not shop aisles end-to-end, but rather, "boomerang" back to the "power aisle" that runs along the cash registers. Shoppers focus on "endcaps," the displays along this power aisle:

Twenty years from now supermarket customers may be like impatient frogs on lily pads, leaping from one destination display to the next. Our children and grandchildren will stop and wonder what we ever meant by "shopping an aisle end to end." (Childress, 2003: 95) 


\section{Endnotes}

1. "High-Tech Shopping Carts" (2005) from CBSNews. com.

2. Investment in the deli sections paid off in the months directly following September 11th as waves of people feeling the bite of recession opted not to eat out, but instead to return to supermarket delis in search of their favorite "comfort foods" (Major, 2002).

3. In the opinion of Mastroianni, Wal-Mart incorporated a grocery store only to lure customers to buy higher-end merchandise, essentially as a gimmick.

4. Baudrillard sought a more radical strategy than Marxism, fearing it insufficient to combat advanced capitalism (Kellner, 2008: 89).
5. Baudrillard suggested, for example, that animals no longer have any corporeal existence but have permanently migrated into the realm of pure signs (1997: 129-142).

6. Facebook gift shop: http://www.facebook.com/ giftshop.php?hns. To begin buying and selling friends, visit "Friends for Sale!": http://www.facebook.com/ apps/application.php?id=7019261521\&ref=s. URLs (consulted 7/08).

\section{References}

Andrejevic, M. (2005). “The Work of Watching One Another: Lateral Surveillance, Risk, and Governance.” Surveillance \& Society, 2(4): 479-497.

Armata, K. (1996). “Signs that sell.” Progressive Grocer, 75(10): 21.

Baudrillard, J. (1994). Simulacra and Simulation. Ann Arbor: University of Minnesota Press.

Baudrillard, J. (1983). “The Ecstasy of Communication.” In H. Foster, Ed., The Anti Aesthetic: Essays on postmodern culture. Port Townsend, WA: Bay Press. Pp. 126-134.

Boorstin, D. (1973). The Americans: The Democratic Experience. New York: Random House.

Childress, C. (2003). “Too close for comfort.” Progressive Grocer, 82(12): 95 .

Childress, C., \& Goldschmidt, B. (2004). "Coming to their senses." Progressive Grocer, 83(9): 94.

Childress, C. (2005). “Sign language.” Progressive Grocer, 83(14): 80-81.

Colicchio, G.L. (2002). “The store of the future.” Progressive Grocer, 81(2): 13-15.

Cross, G. (2000). An All-Consuming Century. New York: Columbia University Press.

Envirosell. (2008). URL (consulted 6/08):

http://www.envirosell.com

“Equipment innovations." (2006). Progressive Grocer, 85(7): 161.
Frazier, M. (2005). "In-store advertising model gains ground by getting up from the floor; Chain tests TV network; analysts say such tactics may turn off shoppers." Advertising Age, 76(18): 10 .

Frazier, M. (2005). "Is Wal-Mart TV a smart buy or defensive one?; Some marketers sign on as goodwill gesture to giant." Advertising Age, 76(38): 3-49, 2 p.

Gatty, B. \& McTaggart, J. (2006). "Get fit.” Progressive Grocer, 85(4): 20-26.

Hammel, F. (1997). “D\&W's home-meal target." Progressive Grocer, 76(10): 117-119.

Heller, W. \& Major, M. (2002). "Gaining ground.” Progressive Grocer, 81(9): 51-55.

"High-Tech Shopping Carts." (2005). CBSNews.com. URL (consulted 6/08):

http://www.cbsnews.com/stories/2005/06/15/eveningnews/ main702172.shtml

“In-store intel." (2005). Progressive Grocer, 84(15): 12.

"In-store health clinics gain traction." (2006). Progressive Grocer, 85(5): 10-13.

Kellner, D. (2008). "Jean Baudrillard (1929-2007)." Communication and Critical/Cultural Studies, 5(1): 88-92.

Koch, A. M. \& Elmore, R. (2006). "Simulation and Symbolic Exchange: Jean Baudrillard's Augmentation of Marx's Theory of Value." Politics \& Policy, 34 (3): 556-575. 
Lewis, L. (1997). “Making meal solutions work." Progressive Grocer, 76(12): 81-85.

Lewis, L. (1997). “W-TV.” Progressive Grocer, 76(12): 9-17.

Lewis, L. (1998). “Uneasy alliance.” Progressive Grocer, 77(3): 58-63.

Lewis, L. (1998). “Box stores.” Progressive Grocer, 77(5): 57-60.

Lewis, L. (1998). “A moveable feast.” Progressive Grocer, 77(12): 19.

Lyon, D. (2003). Surveillance after September 11. Cambridge: Polity.

Major, M. (2002). "Home-cooked comfort." Progressive Grocer, 81(1): 17-21.

Major, M. (2004). “The big cheese.” Progressive Grocer, 83(14): 80-81.

Major, M. \& McTaggart, J. (2003). “The search for insight.” Progressive Grocer, 82(17): 10-13.

Marx, K. (1999, 1887). "Quantitative Determination of Relative Value." In S. Moore and E. Aveling (Trans.), Capitol: Volume One. URL (consulted 6/08):

http://www.marxists.org/archive/marx/works/1867-c1/ch01. htm\#S3a2b

Matthews, R. (1998). "Orphans of the Storm.” Progressive Grocer, $77(2): 22-27$.

McHugh, J. (2004). “Attention Shoppers: You Can Now Speed Straight Through Check Out Lines!” Wired, 12(7). URL (consulted 6/08):

http://www.wired.com/wired/archive/12.07/shoppers_pr.html

Neff, J. (2006). "Murdoch Plans Lock Up the Store." Advertising Age, 77(5): 1-29, 2 p.

“Neon-effect LED lighting." (2005). Progressive Grocer, 84(16): 74 .

O'Harrow, R. (2005). No Place To Hide. New York: Free Press.

"Other concerns: 'Lazy thinking won't be rewarded." (1998). Progressive Grocer, Supplement, 77(4): 22.

Pine, B. \& Gilmore, J. (1999). The Experience Economy. Boston: Harvard Business School Press.

Pizzico, B. (1997). “The Right Kind of Chef." Progressive Grocer, 76(10): 99.
Radice, C. (1997). "Back to basics.” Progressive Grocer, 76(10): 53-58.

Smith, A. (1997). "It's not complicated really." Progressive Grocer, 76(12): 86

Smith, A. (1998). "What a difference a sign makes." Progressive Grocer, 77(1): 47.

Strasser, S. (1989). Satisfaction Guaranteed. New York: Pantheon.

“Targeting the consumer." (1997). Progressive Grocer, 76(12): 52.

Tarnowski, J. (2003). “Ahold's Shopping Buddy.” Progressive Grocer, 82(12): 49-50.

Tarnowski, J. (2003). "Picture perfect." Progressive Grocer, 82(14): 78 .

Tarnowski, J. (2006). “Gone fishin'” Progressive Grocer, 85(12): 98-99.

“The digital shuffle." (2006). Progressive Grocer, 85(10): 83.

“The eyes have it." (1999). Progressive Grocer, 78(7): 97-100.

Turock, A. (2003). "Wal-Mart proofing the store." Progressive Grocer, 82(7): 51-54.

Turow, J. (2006). Niche Envy: Marketing Discrimination in the Digital Age. Cambridge: MIT Press.

Turow, J., Feldman, L., \& Meltzer, K. (2005). "Open to Exploitation: American Shoppers Online and Offline." Report from the Annenberg Public Policy Center of the University of Pennsylvania. URL (consulted 6/08):

http://www.annenbergpublicpolicycenter.org/NewsDetails. aspx?myId $=31$

Turcsik, R. (2001). “Category-weis-er.” Progressive Grocer, 80(9): 45-47.

Turcsik, R. (2001). "Signs of the Times." Progressive Grocer, 80(10): 37-40.

Turcsik, R., \& Summerour, J. (2001). "David vs. Goliath.” Progressive Grocer, 80(3): 7.

Turcsik, R. (2002). “Dawn of the C-MAR era?” Progressive Grocer, 81(6): 40-42.

Turcsik, R. (2003). “In-store marketing 101.” Progressive Grocer, 82(12): 68-70. 